\title{
Propranolol Treatment of Infantile Subglottic Hemangioma: a Report of Two Cases and a Literature Review
}

\author{
Kalina Ganeva ${ }^{1}$, Petar Shivachev ${ }^{1}$, Nikolay Sapundzhiev ${ }^{2}$, Lora Nikiforova ${ }^{2}$ \\ ${ }^{1}$ First Pediatric Clinic, St Marina University Hospital, Varna, Bulgaria \\ ${ }^{2}$ Division of Otorhinolaryngology, St Marina University Hospital, Varna, Bulgaria
}

Corresponding author: Kalina B. Ganeva, First Pediatric Clinic, St Marina University Hospital, 1 Hristo Smirnenski Blvd., Varna, Bulgaria; E-mail: kalinabganeva@gmail.com; Tel.: +359883 396779

Received: 29 Aug $2020 \diamond$ Accepted: 21 Oct $2020 \diamond$ Published: 31 Aug 2021

Citation: Ganeva K, Shivachev P, Sapundzhiev N, Nikiforova L. Propranolol treatment of infantile subglottic hemangioma: a report of two cases and a literature review. Folia Med (Plovdiv) 2021;63(4):601-7. doi: 10.3897/folmed.63.e58121.

\begin{abstract}
Infantile hemangioma is one of the most common benign tumors of infancy. The natural evolution includes rapid growth followed by gradual involution. Airway hemangiomas are not that common, but they can lead to dyspnoea, as well as to life-threatening complications.

Two children aged 3 months were admitted to the Pediatric Department with difficulties in breathing and with biphasic stridor. They had previously been hospitalized because of the same symptoms and misdiagnosed as having an upper respiratory tract infection. The previous treatment included intravenous or inhaled corticosteroids, without any significant improvement. Laryngoscopy was performed for both of the children. There was a mass in the subglottic area with the appearance of a hemangioma causing significant airway stenosis. We started treatment with propranolol at a dose of $1 \mathrm{mg} / \mathrm{kg} /$ day twice daily. The dose was gradually increased up to 3 $\mathrm{mg} / \mathrm{kg} /$ day, under close monitoring. In the first 7 to 10 days after initiation of treatment, we observed a significant improvement of the respiratory distress. The second laryngoscopy showed an almost complete involution of the mass in the subglottis.

The focus of this article will be primarily on the clinical presentation and the therapeutic response of subglottic hemangioma, along with a literature review on the subject.
\end{abstract}

\section{Keywords}

infancy, laryngeal stridor, subglottic hemangioma

\section{INTRODUCTION}

Infantile hemangiomas (IH) are the most common benign tumors of infancy. They appear during the first few days or the first weeks after birth; they grow rapidly followed by gradual involution. Subglottic hemangiomas $(\mathrm{SH})$, commonly located in the subglottis area, are capable of causing airway obstruction. Left without treatment, they can provoke acute respiratory failure with a fatal outcome in
$50 \%$ of the patients. Different therapeutic regimens have been tried in an attempt to resolve quickly the symptoms. This includes intravenous or intralesional corticosteroids, laser surgery, tracheostomy, and surgical resection. In 2008, an accidental discovery radically changed the therapeutic course of $\mathrm{IH}$, including SH. Dr. Léauté-Labrèze and her colleagues demonstrated the remarkable effect of propranolol in the IH treatment. Up until now, the beta-blocker has been the leader in the non-invasive treatment of $\mathrm{IH}$. 
We present our clinical experience with propranolol treatment in two infants with $\mathrm{SH}$. The clinical cases demonstrate a significant resolution of respiratory distress in the first few days after the initiation of the treatment. In this article, we will focus primarily on the clinical presentation and the therapeutic response of $\mathrm{SH}$.

\section{CASE REPORT 1}

A 3-month-old female infant, born at term of normal pregnancy and delivery, with birth weight of $3000 \mathrm{~g}$ and length of $50 \mathrm{~cm}$. There was no family history of any chronic diseases including respiratory problems. At the age of 2 months, an occasional cough occurred, without temperature or any other signs of infection. With time, the child's condition worsened with difficulty in and noisy breathing. The patient had been hospitalized three times in the Pediatric Department because of these symptoms. The treatment consisted of corticosteroids with a temporary effect. Soon after the last hospital discharge, the infant was admitted to our Pediatric Department with signs of severe respiratory distress.

At admission, the child had respiratory failure, biphasic stridor, chest retraction, and blood oxygen saturation of 90\%. The blood test did not show any infection and the chest $X$-ray was without infiltrates. In the differential diagnosis of laryngeal stridor, congenital anomalies of the larynx, vascular rings, and tumors were discussed. A CT contrast scan of the neck and thorax was performed. The results showed the presence of a small, well outlined oval lesion located in the subglottis area, just beneath the left vocal cord. The next diagnostic step was to perform a flexible laryngoscopy. The mass in the subglottis area originated from the transition of the left to the back wall, obstructing two-thirds of the subglottis lumen. The tumour had a smooth visible capillary surface, there was no evidence of active bleeding, and had the appearance of a hemangioma (Fig. 1). There were no hemangiomas on the child's skin. Additional examinations were performed to exclude other internal hemangiomas: transfontanelle and abdominal ultrasound, ECG, and echocardiography.

A therapy with propranolol was started with an initial dose of $1 \mathrm{mg} / \mathrm{kg} / 24$ hour, twice daily, gradually increasing to $3 \mathrm{mg} / \mathrm{kg} / 24$ hours under close surveillance of the respiratory and heart rate, arterial pressure, and blood glucose levels. During the first 7 to 10 days after treatment initiation, a significant respiratory distress improvement was noticed. A second laryngoscopy, performed eight weeks later, showed a demonstrative reduction in the size of the hemangioma (Fig. 2). A control laryngoscopy was performed again, 4.5 months after the initiation of the treatment, showing a slightly elevated residual lesion at the location of $\mathrm{SH}$, causing insignificant airway lumen stenosis (Fig. 3).

Heart and respiratory rate, arterial pressure, and blood sugar levels were monitored at each dose increase. We did not notice any side effects from the treatment. Therapy will continue for 12 months at a target dose of $3 \mathrm{mg} / \mathrm{kg} / 24$ hours.

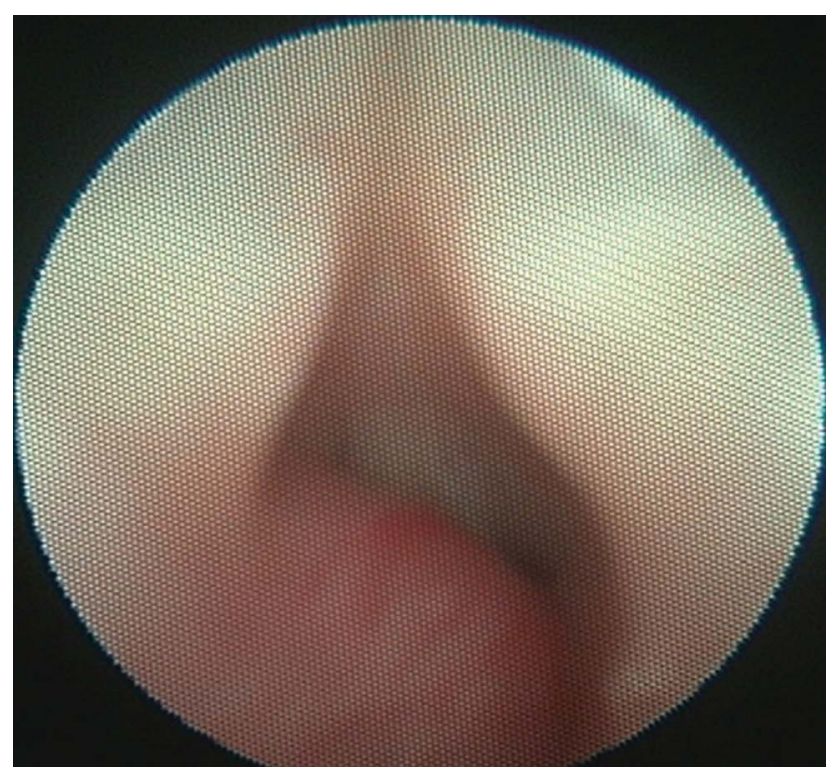

Figure 1. Transnasal flexible fiberoptic laryngoscopy - a tumor mass with a hemangioma appearance located in the subglottis area.

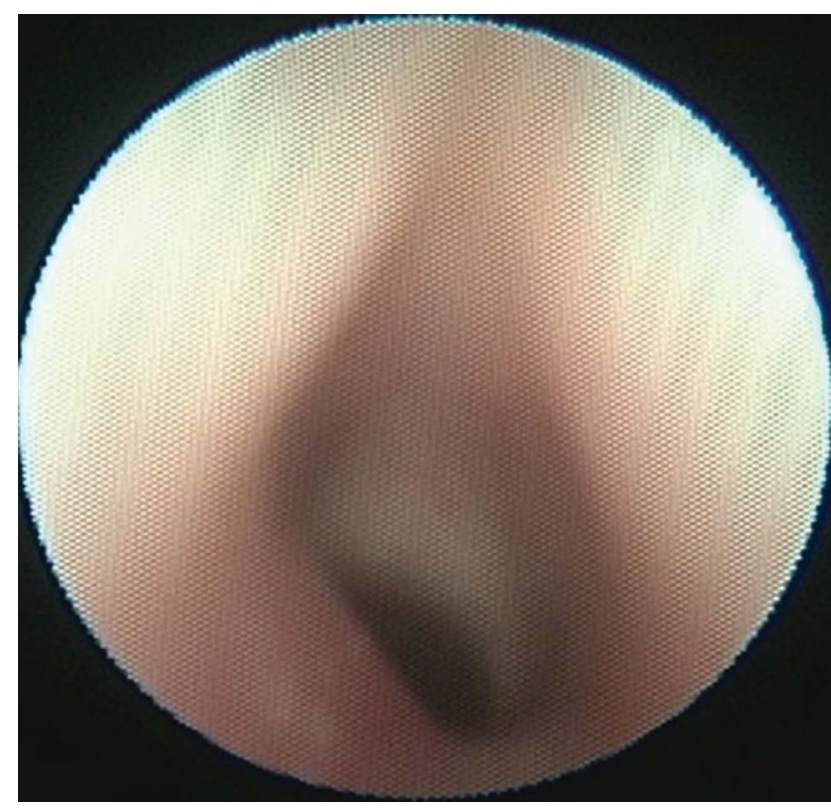

Figure 2. Transnasal flexible fiberoptic laryngoscopy after twomonth treatment - decreased in size hemangioma in the subglottis area.

\section{CASE REPORT 2}

A 3-month-old female infant, born at term of an uneventful pregnancy with birth weight of $2890 \mathrm{~g}$ and length of $45 \mathrm{~cm}$. There was no family history of respiratory diseases. Since the age of 40 days, the child had been suffering from difficult and noisy breathing. There was no evidence of infection. Because of laryngeal stridor, the infant had been hospitalized four times in the Pediatric Department. Treatment was started with corticosteroids with no significant improvement of the condition. 
At admission, the child was in an unsatisfactory condition, with severe biphasic stridor and chest retraction. There was neither temperature nor lung infiltrates. The blood test showed mild hypoxia, with no evidence of inflammation. Transnasal flexible laryngoscopy was performed which showed a red color formation located in the left part of the subglottis. The mass had the appearance of hemangioma and caused $90 \%$ obstruction of the airway (Fig. 4). The formation outspread to the upper part of the trachea, without affecting the supraglottis. Additional examinations such as transfontanelle and abdominal ultrasound, ECG, and echocardiography, were performed to exclude other internal hemangiomas.

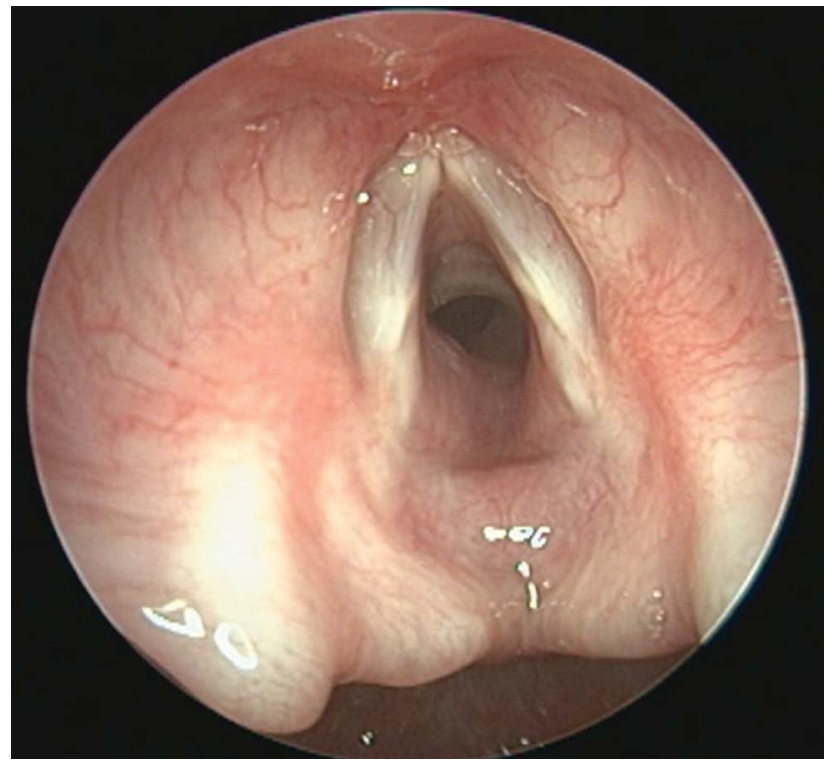

Figure 3. Transoral flexible laryngoscopy via $70^{\circ}$ rigid endoscope 4.5 months later - slightly elevated residual lesion.

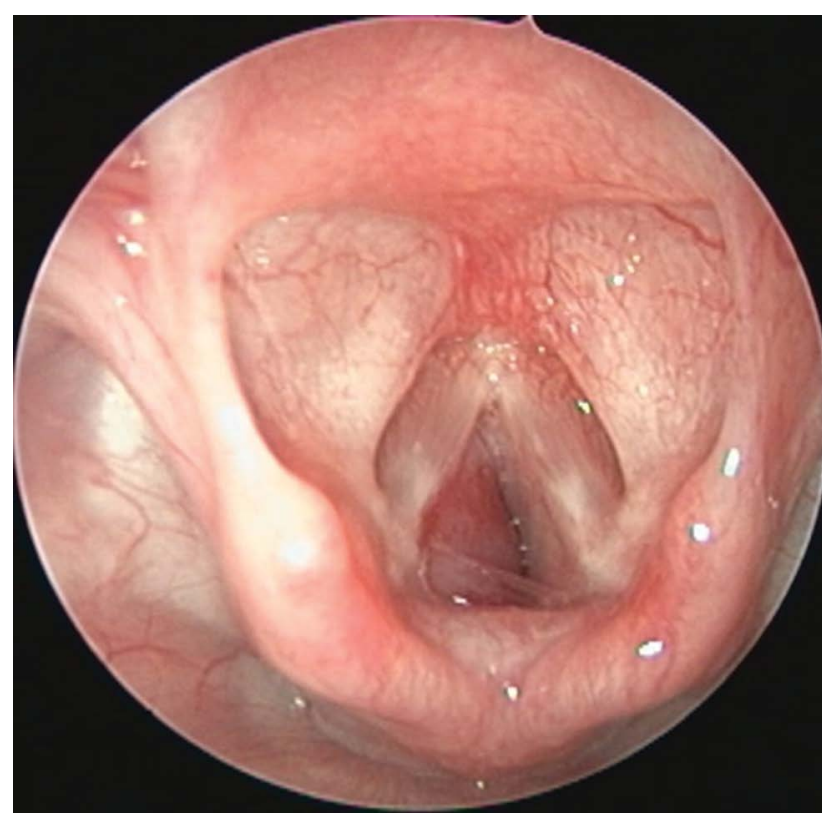

Figure 4. Transnasal flexible laryngoscopy - a hemangioma causing $90 \%$ stenosis of the subglottis lumen.
Despite the significant airway obstruction, therapy with oral propranolol was started under close monitoring of the child's clinical condition. The initial and the target doses were $1 \mathrm{mg} / \mathrm{kg} /$ day and $3 \mathrm{mg} / \mathrm{kg} /$ day, respectively, given twice daily. Within the first 14 days of the treatment, we observed a decrease in respiratory distress and stridor.

Thirteen weeks later, a second laryngoscopy showed only a slightly hyperemic mucosa on the place of hemangioma. There was no airway stenosis (Fig. 5). We did not notice any side effects during the treatment.

Summarized data for the two infants are shown in Tables 1 and 2.

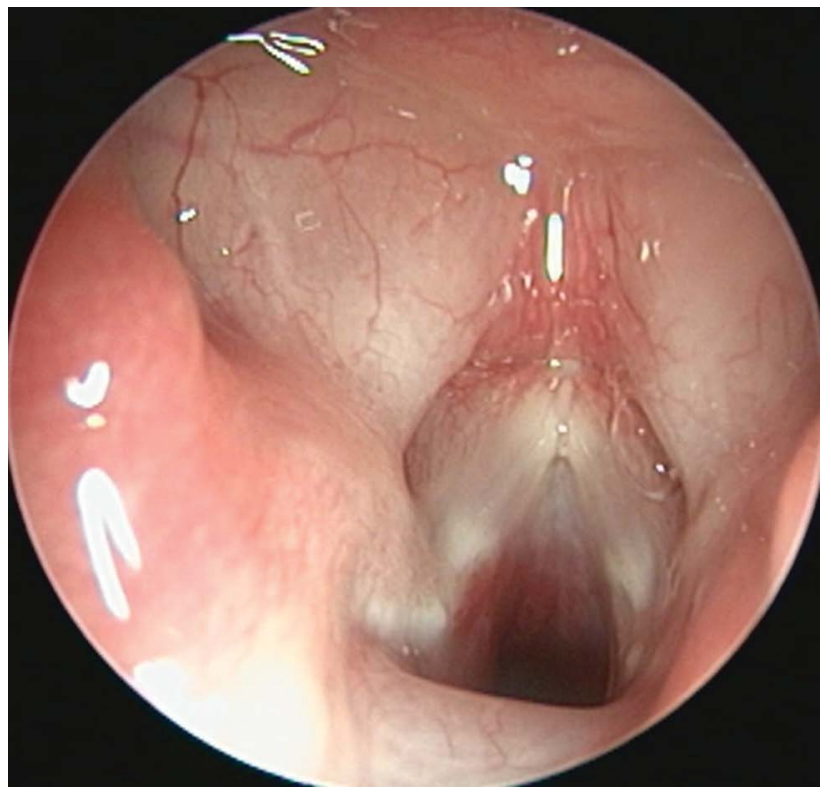

Figure 5. Transnasal flexible laryngoscopy 13 weeks later showed a slightly hyperemic mucosa on the place of the hemangioma.

\section{DISCUSSION}

Infantile hemangiomas (IH) are benign vascular tumors that occur most often in the first days or a few weeks after the birth. They have a rapid growth in the first months of life, the so-called proliferative phase, followed by an involutional phase typically beginning around 1 year of age. ${ }^{1}$ Most hemangiomas are not visible immediately after birth, but reach $80 \%$ of their final size by the age of 5 months. ${ }^{1,2}$

The pathogenesis of $\mathrm{IH}$ is based on the ability of certain cells, called stem cells or progenitor cells, to differentiate into endothelial cells, pericytes, and adipocytes. ${ }^{3}$ The exact origin of these cells has not yet been defined. What has been found is that they are up to $1 \%$ of all cells during the proliferative phase of IH development.

Another key point in the pathogenesis of IH is hypoxia. The assumption that hypoxia may play a role is based on the elevated levels of certain substances, the production of which is provoked by hypoxia. These include vascular 
Table 1. Summarized data for the two infants

\begin{tabular}{lllllll}
\hline Patient & $\begin{array}{l}\text { Age at onset } \\
\text { of first } \\
\text { clinical } \\
\text { symptoms }\end{array}$ & $\begin{array}{l}\text { Clinical } \\
\text { symptoms }\end{array}$ & Diagnosis via & Localization & $\begin{array}{l}\text { Previous } \\
\text { treatment }\end{array}$ & $\begin{array}{l}\text { Other } \\
\text { hemangiomas }\end{array}$ \\
\hline 2 months & $\begin{array}{l}\text { Biphasic stridor, } \\
\text { chest retractions, } \\
\text { respiratory failure }\end{array}$ & $\begin{array}{l}\text { Laryngoscopy, } \\
\text { CT scan }\end{array}$ & $\begin{array}{l}\text { Subglottis area on } \\
\text { the left wall }\end{array}$ & $\begin{array}{l}\text { Corticosteroids } \\
\text { (intravenous, inha- } \\
\text { latory) }\end{array}$ & No \\
& $\begin{array}{l}\text { Biphasic stridor, } \\
\text { chest retractions }\end{array}$ & Laryngoscopy & $\begin{array}{l}\text { Subglottis area, up- } \\
\text { per part of trachea, } \\
\text { on the left }\end{array}$ & $\begin{array}{l}\text { Corticosteroids } \\
\text { (intravenous) }\end{array}$ & No \\
\hline
\end{tabular}

Table 2. Summarized data for the two infants

\begin{tabular}{lllllll}
\hline Patient & $\begin{array}{l}\text { Beginning of } \\
\text { therapy with } \\
\text { propranolol }\end{array}$ & $\begin{array}{l}\text { Clinical effect } \\
\text { of treatment }\end{array}$ & $\begin{array}{l}\text { Following up } \\
\text { (control } \\
\text { laryngoscopy) }\end{array}$ & Results & $\begin{array}{l}\text { Duration } \\
\text { of treatment }\end{array}$ & Side effects \\
\hline & & First week & 8 week; 4.5 months & $\begin{array}{l}\text { Slightly elevated } \\
\text { lesion, insignifi- } \\
\text { cant airway lumen } \\
\text { stenosis }\end{array}$ & 12 months \\
1 & 3 months & No hemangioma, \\
1 & 3 months & $1-2$ weeks & 13 week & $\begin{array}{l}\text { normal airway } \\
\text { lumen }\end{array}$ & 6 months & No \\
\hline
\end{tabular}

endothelial growth factor A (VEGF-A), glucose transporter (GLUT-1), and IGF-2, which are found in high concentrations during the proliferative phase of $\mathrm{IH}$ growth. ${ }^{4}$

The location and size of the hemangiomas are directly related to complications some of which are even life-threatening. Examples are hemangiomas localized in the airways, hemangiomas that can lead to disfigurement and permanent scars, or hemangiomas that can cause dysfunction of an organ or system.

Subglottic hemangiomas ( $\mathrm{SH}$ ) are classified as lifethreatening. Due to their specific location, they can cause an airway obstruction during the proliferative phase with a potentially fatal outcome. The localization is in most cases subglottic, more often on the left side than on the right ${ }^{5}$, as in the patients we observed. Unilateral, bilateral, hemangiomas covering the supraglottic space, circumferential subglottic lesions, as well as hemangiomas in the upper part of the trachea have been described. ${ }^{6}$ In more than half of patients with $\mathrm{SH}$, cutaneous hemangiomas are also observed, primarily in the area of the chin, lower jaw and lip, in the preauricular area and on the anterior surface of the neck. The absence of cutaneous hemangiomas, as in the cases we present, makes early diagnosis difficult. Orlow et al. ${ }^{9}$ reported an association between symptomatic upper airway and subglottic hemangiomas, and cutaneous hemangiomas in the chin area in up to $63 \%$ of cases.

$\mathrm{SH}$ is thought to account for $1.5 \%$ of congenital laryngeal abnormalities. ${ }^{10}$ Histological and immunohistochemical evidence confirms the fact that SHs are classic infantile rather than congenital hemangiomas. ${ }^{5}$ The endothelial cells of the IH demonstrate a high expression of GLUT-1 (glucose transporter-1), which allows them to be differentiated from other types of vascular malformations and tumors. ${ }^{11}$ The few congenital hemangiomas studied lacked GLUT-1 expression, in contrast to SHs, in which GLUT-1 is highly expressed. ${ }^{12}$ On the other hand, unlike $\mathrm{IH}$, congenital hemangiomas are fully formed at birth and may regress during the first 8-14 months of life. ${ }^{12}$

Therefore, the course of SH development is identical to that of the cutaneous $\mathrm{IH}$ - they are both characterized by a rapid proliferative phase during which progressive airway obstruction is observed. Evidence of this is the onset of stridor with progressive respiratory distress in the first months of life. The most common initial clinical manifestation of $\mathrm{SH}$ is the biphasic stridor with respiratory distress almost always manifested up to 4 months of age. ${ }^{13}$

Voice quality is usually not affected. A croup-like cough, along with a deterioration of stridor and respiratory function over time, might be observed. ${ }^{9}$ Often, the initial symptoms are misdiagnosed as an upper respiratory tract infection or laryngomalacia. The presence of cutaneous hemangiomas would suggest the possibility of developing hemangiomas in the airways. But this is not always the case, as in the patients presented by us.

The diagnosis of $\mathrm{SH}$ is based on clinical symptoms and imaging studies including laryngoscopy, CT, and contrast MRI. The typical laryngoscopic image of $\mathrm{SH}$ is a dark red or purple tumor mass located in the subglottic region. The 
endoscopic finding is not entirely specific and therefore CT and MRI with contrast are useful in defining the vascular nature of the lesion, as well as in assessing the degree of tracheal invasion. ${ }^{14}$

Even though a large percentage of IH regress spontaneously, in cases of life-threatening localization, immediate treatment is required. If left untreated, SHs have a high mortality rate of up to $50 \% .{ }^{15}$ Until 2008 , treatment options for complicated IH included intravenous and intralesional corticosteroids ${ }^{16}$, laser surgery, and in severe cases, cytostatics such as vincristine and cyclophosphamide ${ }^{17}$. Each of these treatments carries a risk of many serious side effects. In 2008, Dr. Léauté-Labrèze and her colleagues accidentally discovered the remarkable effect of propranolol in the treatment of $\mathrm{IH}^{18}$ and the non-selective beta-blocker became a gold standard therapy. A 2011 literature review ${ }^{19}$ compares the effect of treating IH with propranolol on the one hand, and steroids, laser surgery, and vincristine on the other. Propranolol was found to be significantly more effective than other treatments. Moreover, the therapy is noninvasive, fast-acting, and cost-effective.

According to the current recommendations of the American Pediatric Association from 2019, the beta-blocker is the first-line medication for $\mathrm{IH}$ requiring systemic treatment. ${ }^{1}$ Its therapeutic effect is based on vasoconstriction and inhibition of angiogenesis. ${ }^{17}$ Vascular tone is regulated by the autonomic nervous system through alpha and beta receptors which are expressed on the endothelial cells. Activation of beta 2-receptors triggers a cascade of molecular reactions that lead to the release of nitric oxide with subsequent vascular smooth muscle relaxation and vasodilation. The non-selective beta-blocker inhibits these processes and thus causes vasoconstriction of the hemangioma-feeding capillaries. This leads to visible changes - fading of the color of hemangioma in the first days of treatment. Rapid regression of respiratory distress was observed in our patients with $\mathrm{SH}$ in this initial stage of therapy. The longterm effect of the beta-blocker action is due to the reduced expression of VEGF and inhibition of angiogenesis. Propranolol significantly inhibits the growth of hemangioma stem cells but does not induce true apoptosis of these cells. ${ }^{20}$

The recommendations include an initial dose of $1 \mathrm{mg} /$ $\mathrm{kg} / 24$ hours with a gradual increase to $2-3 \mathrm{mg} / \mathrm{kg} / 24$ hours over 2 weeks, with heart rate, blood pressure, blood glucose, and lung status monitoring. ${ }^{1}$ There is no information on whether a target dose of $2 \mathrm{mg} / \mathrm{kg} /$ day is more effective than $3 \mathrm{mg} / \mathrm{kg} /$ day. The effect of treatment is observed in the first few days from 24 hours to 3 weeks, an average of 3.8 days, with rapid improvement in clinical symptoms and regression of the stridor. ${ }^{19,21}$ Given the low incidence and prevalence of $\mathrm{SH}$, meta-analyses and clinical series published in the literature cover only a small number of patients. However, all described a significant reduction in the degree of respiratory obstruction, ranging from $50 \%$ to $64 \%$ within the first $1-2$ weeks of treatment. ${ }^{7,19}$ The fact that concomitant treatment with propranolol and corticosteroids is associated with a higher risk of failure should be taken into consideration. ${ }^{22}$ As already mentioned, the initial symptoms are often misdiagnosed as an upper respiratory tract infection and corticosteroid therapy is initiated. Both infants presented herein had several hospitalizations due to recurrent symptoms of respiratory distress and breathing difficulties, during which corticosteroid therapy was performed, but with a short-term effect. One can conclude that frequent episodes of respiratory dyspnea requiring hospitalizations, with short-term effectiveness of corticosteroid treatment, suggest the need for endoscopic examination.

Symptomatic bradycardia, arterial hypotension, hypoglycemia, sleep disturbances, and bronchial hyperreactivity have been reported as potential side effects of treatment with a non-selective beta-blocker. In children without evidence of underlying heart disease or broncho-obstructive syndrome, the risk of side effects is minimal. However, current recommendations include the monitoring of heart rate, blood pressure, blood glucose, and lung status during the first 2 hours after the first dose of propranolol and with each subsequent dose increase. In high-risk patients, the lowest effective dosage and slow titration are recommended. ${ }^{1}$

The treatment should be administered for at least 6 months as the optimal option is until the age of 1 year. $^{1}$ Cases of relapse have been reported with $\mathrm{SH}$ treatment for less than 6 months. ${ }^{7}$ On the other hand, the risk of recurrence (from $10 \%$ to $25 \%$ ) exists even after a 6-month therapy course, especially when discontinued earlier than 9 months of age. The lowest risk of recurrence is observed when treatment is stopped between 12 and 18 months of age. $^{23}$

\section{CONCLUSIONS}

Subglottic hemangiomas, although rare, can be life threatening with a risk of upper airway obstruction during the first months of a child's life. Current treatment recommendations are for the use of a non-selective beta-blocker, as the therapy is non-invasive, with minimal risk of side effects and, last but not least, with a demonstrative clinical effect. Our observations found a rapid reduction in respiratory symptoms, demonstrating the successful use of propranolol in the non-invasive treatment of subglottic hemangiomas. Flexible laryngoscopy today is an easy-to-perform, minimally invasive test for diagnosing $\mathrm{SH}$, as well as for tracking and objectifying the effect of the therapy.

\section{Learning points/Take home messages:}

- Raise the attention of clinicians to differential diagnose of respiratory stridor in infancy.

- The initial symptoms of subglottic hemangioma often can be misdiagnosed as an upper respiratory tract infection.

- Frequent episodes of respiratory dyspnea in infancy requiring hospitalizations, with short-term effectiveness of corticosteroid treatment, suggest the need for endoscopic examination. 


\section{Funding}

The authors have no funding to report.

\section{Competing interest}

The authors have declared that no competing interests exist.

\section{Acknowledgements}

The authors have no support to report.

\section{REFERENCES}

1. Krowchuk D, Frieden I Mancini A, et al. Clinical practice guideline for the management of infantile hemangioma. Pediatrics January 2019; 143(1):e20183475.

2. Chang L, Haggstrom A, Drolet B, et al. Growth characteristics of infantile hemangiomas: implications for management. Pediatrics 2008; 122(2):360-7.

3. Greenberger S, Bischoff J. Pathogenesis of infantile hemangioma. Br J Dermatol 2013; 169(1):12-19.

4. de Jong $\mathrm{S}$, Itinteang $\mathrm{T}$, Withers $\mathrm{AH}$, et al. Does hypoxia play a role in infantile hemangioma? Arch Dermatol Res 2016; 308(4):219-27.

5. Badi AN, Kerschner JE, North PE, et al. Histopathologic and immunophenotypic profile of subglottic hemangioma: multicenter study. Int J Pediatr Otorhinolaryngol 2009; 73(9):1187-91.

6. Rahbar R, Nicollas R, Roger G, et al. The biology and management of subglottic hemangioma: past, present, and future. The Laryngoscope 2004; 114(11):1880-91.

7. Leboulanger N, Fayoux P, Teissier N, et al. Propranolol in the therapeutic strategy of infantile laryngotracheal hemangioma: a preliminary retrospective study of French experience. Int J Pediatr Otorhinolaryngol 2010; 74(11):1254-7.

8. Ding X, Zhong L, Zhang B, et al. Clinical diagnosis and oral propranolol curative effect analysis of infant subglottic hemangioma. Int J Clin Exp Med 2020; 13(2):1014-22.

9. Orlow SJ, Isakoff MS, Blei F. Increased risk of symptomatic heman- giomas of the airway in association with cutaneous hemangiomas in a "beard" distribution. J Pediatr 1997; 131(4):643-6.

10. Holinger PH, Brown WT. Congenital webs, cysts, laryngoceles and other anomalies of the larynx. Ann Otol Rhinol Laryngol 1967; 76:744-52.

11. North PE, Waner M, Mizeracki A, et al. GLUT1: a newly discovered immunohistochemical marker for juvenile hemangiomas. Hum Pathol 2000; 31(1):11-22.

12. van Vugt LJ, van der Vleuten CJ, Flucke U, et al. The utility of GLUT1 as a diagnostic marker in cutaneous vascular anomalies: A review of literature and recommendations for daily practice. Pathol Res Pract 2017; 213(6):591-7.

13. Sherrington CA, Sim DK, Freezer NJ, et al. Subglottic haemangioma. Arch Dis Child 1997; 76(5):458-9.

14. Robitaille C, Fortin M, Trahan S, et al. Subglottic Hemangioma. J Bronchology Interv Pulmonol 2016; 23(3):232-5.

15. Ferguson CF, Flake CG. Subglottic hemangioma as a cause of respiratory obstruction in infants. Ann Otol Rhinol Laryngol 1961; 70:1095-112.

16. Greene AK, Couto RA. Oral prednisolone for infantile hemangioma: efficacy and safety using a standardized treatment protocol. Plast Reconstr Surg 2011; 128(3):743-52.

17. Storch $\mathrm{CH}$, Hoeger PH. Propranolol for infantile haemangiomas: insights into the molecular mechanisms of action. Br J Dermatol 2010; 163(2):269-74.

18. Léauté-Labrèze C, de la Roque ED, Hubiche T, et al. Propranolol for severe hemangiomas of infancy. N Engl J Med 2008; 358:2649-51.

19. Peridis S, Pilgrim G, Athanasopoulos I, et al. A meta-analysis on the effectiveness of propranolol for the treatment of infantile airway haemangiomas. Int J Pediatr Otorhinolary 2011; 75(4):455-60.

20. Kum JJ, Khan ZA. Propranolol inhibits growth of hemangiomainitiating cells but does not induce apoptosis. Pediatr Res 2014; 75(3):381-8.

21. Truong MT, Perkins JA, Messner AH, et al. Propranolol for the treatment of airway hemangiomas: a case series and treatment algorithm. Int J Pediatr Otorhinolary 2010; 74(9):1043-8.

22. Hardison S, Wan W, Dodson KM. The use of propranolol in the treatment of subglottic hemangiomas: a literature review and meta-analysis. Int J Pediatr Otorhinolaryngol 2016; 90:175-80.

23. Shah SD, Baselga E, McCuaig C, et al. Rebound growth of infantile hemangiomas after propranolol therapy. Pediatrics 2016; 137(4):e20151754. 


\title{
Лечение пропранололом детской подсвязочной гемангиомы: отчёт о двух случаях и обзор литературы
}

\author{
Калина Ганева ${ }^{1}$, Петар Шивачев ${ }^{1}$, Николай Сапунджиев ${ }^{2}$, Лора Никифорова ${ }^{2}$ \\ ${ }^{1}$ Первая педиатрическая клиника, УМБАЛ „Св. Марина“, Варна, Болгария \\ ${ }^{2}$ Клиника оториноларингологии, УМБАЛ „Св. Марина“, Варна, Болгария
}

Адрес для корреспонденции: Калина Ганева, Первая педиатрическая клиника, УМБАЛ „Св. Марина“, бул. „Христо Смирненски“ №1, Варна, Болгария; E-mail: kalinabganeva@gmail.com; Тел.: +359 883396779

Дата получения: 29 августа 2020 Дата приемки: 21 октября 2020 Дата публикации: 31 августа 2021

Образец цитирования: Ganeva K, Shivachev P, Sapundzhiev N, Nikiforova L. Propranolol treatment of infantile subglottic hemangioma: a report of two cases and a literature review. Folia Med (Plovdiv) 2021;63(4):601-7. doi: 10.3897/folmed.63.e58121.

\begin{abstract}
Резюме
Детская гемангиома - одна из самых распространённых доброкачественных опухолей в детском возрасте. Естественная эволюция предполагает быстрый рост, за которым следует постепенная инволюция. Гемангиомы дыхательных путей встречаются реже, но они могут привести к одышке, а также к опасным для жизни осложнениям. В педиатрическое отделение поступили двое детей в возрасте 3 месяцев с затруднённым дыханием и двухфазным хрипом. Раньше они были госпитализированы с теми же симптомами и ошибочно диагностировали инфекцию верхних дыхательных путей. Предыдущее лечение включало внутривенные и ингаляционные кортикостероиды без значительного улучшения. Обоим детям была сделана ларингоскопия. Было обнаружено, что образование, подобное гемангиоме в подсвязочной области, вызывает значительный стеноз дыхательных путей. Мы начали лечение пропранололом в дозе 1 мг/кг/сут. в два приёма. Дозу постепенно увеличивали до 3 мг/кг/сут. под тщательным наблюдением. В течение первых 7-10 дней после начала лечения мы наблюдали значительное улучшение респираторных расстройств. Вторая ларингоскопия показала практически полную инволюцию образования в подсвязке. Основное внимание в этой статье уделяется клинической картине и терапевтическому ответу на подсвязочные гемангиомы, а также обзору литературы по этому вопросу.
\end{abstract}

\section{Ключевые слова}

детский возраст, стридор гортани, подсвязочная гемангиома 